\title{
Arbuscular Mycorrhizal Fungi and Associated Microbiota as Plant Biostimulants: Research Strategies for the Selection of the Best Performing Inocula
}

\author{
Luca Giovannini ${ }^{1,+}{ }^{\dagger}$, Michela Palla ${ }^{1,+}$, Monica Agnolucci ${ }^{1}$, Luciano Avio ${ }^{1}{ }^{\circledR}$, \\ Cristiana Sbrana ${ }^{2}{ }^{-}$, Alessandra Turrini ${ }^{1}$ and Manuela Giovannetti ${ }^{1, *}$ \\ 1 Department of Agriculture, Food and Environment, University of Pisa, Via del Borghetto 80, \\ 56124 Pisa, Italy; luca.giovannini@phd.unipi.it (L.G.); michela.palla@for.unipi.it (M.P.); \\ monica.agnolucci@unipi.it (M.A.); luciano.avio@unipi.it (L.A.); alessandra.turrini@unipi.it (A.T.) \\ 2 CNR, Institute of Agricultural Biology and Biotechnology, UOS Pisa, Via Moruzzi 1, 56124 Pisa, Italy; \\ sbrana@ibba.cnr.it \\ * Correspondence: manuela.giovannetti@unipi.it; Tel.: +39-050-221-6643 \\ + These Authors share the first Authorship.
}

Received: 18 December 2019; Accepted: 9 January 2020; Published: 11 January 2020

\begin{abstract}
Arbuscular mycorrhizal fungi (AMF) are beneficial soil microorganisms establishing mutualistic symbioses with the roots of the most important food crops and playing key roles in the maintenance of long-term soil fertility and health. The great inter- and intra-specific AMF diversity can be fully exploited by selecting AMF inocula on the basis of their colonization ability and efficiency, which are affected by fungal and plant genotypes and diverse environmental variables. The multiple services provided by AMF are the result of the synergistic activities of the bacterial communities living in the mycorrhizosphere, encompassing nitrogen fixation, P solubilization, and the production of phytohormones, siderophores, and antibiotics. The tripartite association among host plants, mycorrhizal symbionts, and associated bacteria show beneficial emerging properties which could be efficiently exploited in sustainable agriculture. Further in-depth studies, both in microcosms and in the field, performed on different AMF species and isolates, should evaluate their colonization ability, efficiency, and resilience. Transcriptomic studies can reveal the expression levels of nutrient transporter genes in fungal absorbing hyphae in the presence of selected bacterial strains. Eventually, newly designed multifunctional microbial consortia can be utilized as biofertilizers and biostimulants in sustainable and innovative production systems.
\end{abstract}

Keywords: arbuscular mycorrhizal symbiosis; mycorrhizosphere; AMF associated bacteria; plant growth-promoting bacteria; biofertilizers; phosphate-solubilizing bacteria; siderophore production

\section{Introduction}

In the next decades, the major challenge for agriculture will be the adoption of a new paradigm, sustainable intensification, to meet human needs for the production of enough food at a global scale while maintaining environmental quality and reducing the input of chemical fertilizers and pesticides [1]. These objectives may be pursued by giving more attention to beneficial soil microorganisms that play key roles in the maintenance of long-term soil fertility and health, the reduction of chemical inputs in agriculture, the promotion of plant nutrition, and the production of safe and high-quality food [2]. Among them, arbuscular mycorrhizal (AM) fungi (AMF) represent a key functional group, positively affecting plant growth, nutrition, and health. AMF are obligately biotrophic organisms that establish 
mutualistic symbioses with the roots of all major land plant taxa, including the most important food crops such as cereals, pulses, fruit trees, vegetables, medicinal plants, and other economically relevant species such as sunflower, cotton, sugarcane, tobacco, coffee, tea, cocoa, rubber, and cassava [3]. Within food crops, the only exceptions are represented by genera and species belonging to Brassicaceae and Chenopodiaceae, which are non-mycorrhizal plants.

In exchange for plant photosynthates, AMF facilitate the uptake and transfer of mineral nutrients, such as phosphorus $(\mathrm{P})$, nitrogen $(\mathrm{N})$, sulfur, potassium, calcium, copper and zinc, from the soil to their host plants by means of the extraradical mycelium (ERM) extending from colonized roots into the soil [3]. Such a fungal structure represents one of the critical elements of the AM symbiosis, as the flow of nutrients translocated to the root cells of host plants is highly dependent on its structure, extent, and interconnectedness. ERM functions as an efficient absorbing system, given the high surface-to-volume ratio of the mycelium, which is able to uptake soil nutrients beyond the depletion zone around roots, and the presence of nutrient transporter genes in the hyphae [4]. Besides plant nutrition improvement, AMF facilitate the completion of biogeochemical cycles, increase plant tolerance to biotic and abiotic stresses, carbon sequestration and soil aggregation [5], and the content of health-promoting phytochemicals [6,7] (Figure 1).

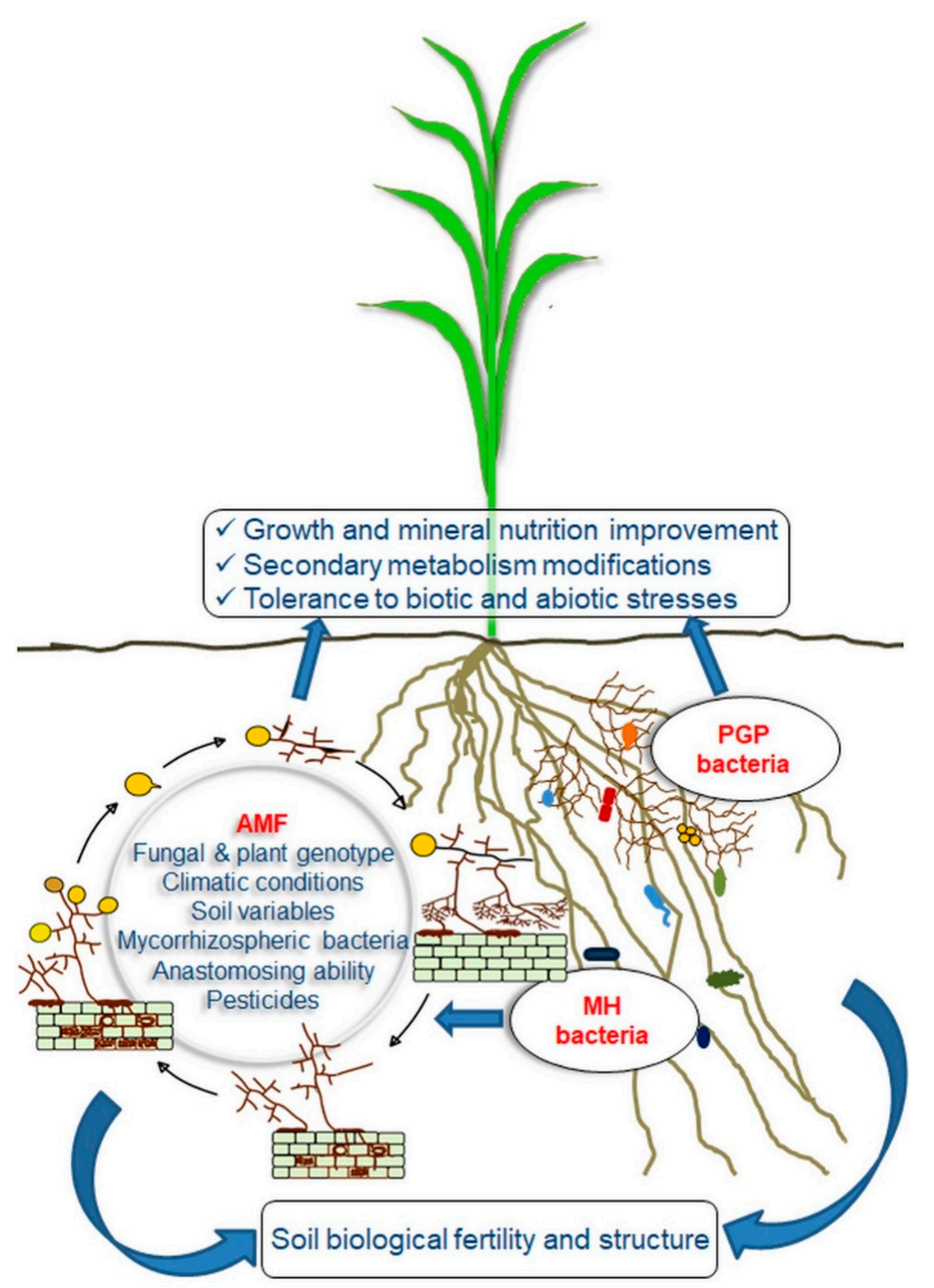

Figure 1. Schematic drawing representing the impacts of arbuscular mycorrhizal fungi (AMF) and beneficial bacteria on plant performance and soil fertility. On the left: a visual representation of the AMF life cycle and factors affecting the different AMF developmental stages; on the right: mycorrhizal helper (MH) and plant growth promoting (PGP) bacteria synergistically interacting with AMF. 
Several studies showed that the multiple services provided by AMF are the result of the synergistic activity of diverse bacterial communities living in the mycorrhizosphere, strictly associated with their spores and extraradical mycelium and playing diverse plant growth-promoting (PGP) roles, from nitrogen fixation and $\mathrm{P}$ solubilization and mineralization to the production of indole acetic acid (IAA), siderophores, and antibiotics [8,9]. Such microbiota was identified not only by culture-independent methods but also by culture-dependent approaches, which allowed their functional characterization, aimed at detecting the best performing bacterial strains, to be used in combination with selected AMF as biofertilizers and biostimulants in innovative and sustainable food production systems [10].

The aim of this review is to provide an overview of the recent developments which contributed to disclose the biostimulant properties of AMF and their associated bacteria and to propose the best research strategies for the selection of functional isolates and consortia to be utilized as high-quality inocula in sustainable agriculture.

\section{Arbuscular Mycorrhizal Fungi}

AMF belong to the phylum Glomeromycota, encompassing ten out of eleven families: Acaulosporaceae, Ambisporaceae, Archaesporacea, Claroidoglomeraceae, Diversisporaceae, Gigasporaceae, Glomeraceae, Pacisporaceae, Paraglomeraceae, and Sacculosporaceae (http://www.amfphylogeny.com/, accessed on 7 January 2020). Given their status of obligate biotrophs, the AMF life cycle cannot be completed in the absence of host plants. It starts with an asymbiotic phase, during which spores germinate in response to physical factors such as moisture, temperature and $\mathrm{pH}$, producing hyphae with a limited lifespan [11]. In the presence of root exudates from host plants, a differential hyphal morphogenesis occurs, with germling hyphae reorienting the direction of elongation and initiating a differential branching pattern [12-14]: this pre-symbiotic phase is followed by physical contact between AMF hyphae and host roots, with the differentiation of appressoria, which give rise to hyphae growing intercellularly within the root cortex, eventually penetrating in root cells and producing highly branched hyphal tree-like structures similar to haustoria, the arbuscules. Arbuscules are the key structures of mycorrhizal symbioses, as at their level nutrient exchanges between the two partners take place: AMF obtain carbon (up to $20 \%$ of plant photosynthates) and lipids from the host plant and release mineral nutrients absorbed and translocated by ERM [15-17]. Two types of root colonization have been detected: Arum-type and Paris-type [3]. In the Arum-type, the AM symbiont spreads intercellularly between cortical root cells, forming terminal arbuscules on intracellular hyphal branches [18]. In the Paris-type, the fungus grows directly from cell to cell within the cortex and forms intracellular hyphal coils and intercalary arbuscules along the coils. However, most of the data available on AMF derive from studies carried out on the Arum-type mycorrhizal symbioses, which are widely distributed in natural and agricultural ecosystems. Beyond arbuscules, several AMF species produce intraradical vesicles, which are spore-like storage structures containing lipids. After receiving host carbon, the fungal symbiont is able to grow extraradically, colonize the surrounding soil, absorb mineral nutrients to be transferred to the host plant, interact with rhizosphere and soil microorganisms, colonize the roots of other plant living nearby (even belonging to species, genera and families different from their host), and also translocate mineral nutrients from one host to another $[19,20]$. The life cycle is closed by the formation of asexual spores by ERM, functional to the maintenance of a high mycorrhizal potential of the soil and, consequently, of soil biological fertility (Figure 1).

\section{AMF Functional Diversity: Colonization Ability and Efficiency}

So far, 323 AMF species have been described (http://www.amf-phylogeny.com/amphylo_species. $\mathrm{html}$, accessed 3 December 2019), though only a few species have been investigated for their functional diversity, in order to detect and select the best isolates to be used in agriculture. As a consequence, most of the available commercial inocula are prepared with Rhizoglomus irregulare (syn. Rhizophagus irregularis, formerly Glomus intraradices) and Funneliformis mosseae (formerly Glomus mosseae), that are generalist symbionts, widespread all over the world in almost all soils and climatic zones [3]. In order 
to exploit the great inter- and intra-specific diversity, the general criteria to be applied when selecting the most efficient AMF isolates are outlined here.

The two fundamental fungal characteristics to be taken into account are colonization ability, which refers to fungal capacity of a rapid and extensive root colonization, and efficiency, represented by fungal symbiotic performance, in terms of plant growth and nutrition.

\subsection{Colonization Ability}

A high root colonization ability is the essential prerequisite for any AMF isolate to be designed for agricultural utilization, as it should be able to compete with highly competitive native AMF. AMF colonization ability does not depend only on fungal genotype, but also on soil characteristics and plant genotype, which may influence the different steps of mycorrhizal establishment, from spore germination to appressorium formation and intraradical growth.

The first variable affecting the competitive ability of an AMF strain is represented by spore dormancy, which may be relieved by storage at $5-10{ }^{\circ} \mathrm{C}$ for $5-6$ weeks; nevertheless, it is extremely important to know which AMF isolates produce dormant spores when selecting strains for inoculation. As an example, different species of the genera Glomus, Funneliformis, and Acaulospora show spore dormancy, while species such as Gigaspora gigantea and Gigaspora margarita are able to germinate as early as one day after incubation [21]. It is unfortunate that only a few works have investigated this critical element, which should be further studied not only at the species but, most importantly, at the isolate level, as the producers of commercial inocula often reproduce their own strains.

A key fungal characteristic directly linked to AMF establishment and persistence in the field is represented by spore germination, which is affected by different factors such as soil $\mathrm{pH}$ and nutrient content, temperature, soil bacteria, and pesticides. Poor information is available on soil variables, suggesting that the different AMF strains show optimum germination when cultivated in environments with characteristics similar to those from which they were originally isolated. Thus, for example, Acaulospora laevis, predominant in low $\mathrm{pH}$ soils, germinates well at $\mathrm{pH} 4-5$, while Dentiscutata heterogama (formerly Gigaspora heterogama), isolated from warm climates, germinates best at $34{ }^{\circ} \mathrm{C}$ [21], although nine $\mathrm{AMF}$, isolated and maintained in tropical areas, showed very different germination rates, ranging from $8 \%$ to $78 \%$, when cultured in the same environmental conditions [22]. It has long been known that spore germination can be stimulated by soil microorganisms, from Actinobacteria to Pseudomonads, although the most relevant role is played by bacteria living in intimate association with AMF, often located on and within spore wall layers (mycorrhizospheric bacteria) [9]. Actually, many bacterial taxa able to degrade biopolymers were recently detected in spore homogenates by culture-independent methods, suggesting a possible chitinolytic activity on chitin of spore walls that could enhance spore germination [23,24]. It is interesting to note that a recent molecular work reported the ability of six AMF isolates to recruit different bacterial communities on their spores, belonging to Actinomycetales, Bacillales, Burkholderiales, Pseudomonadales, and Rhizobiales, possibly exerting an activity on spore germination [25]. As to pesticides, their effects on spore germination are different depending on the target organisms. Several fungicides, like copper hydroxide and mancozeb, were able to inhibit spore germination of $F$. mosseae in vivo, while flutolanil, azoxystrobin, fenpropimorph, and fenhexamid inhibited germination of $R$. irregulare spores in vitro [26,27]. On the other hand, other fungicides, such as fosetil $\mathrm{Al}$, metalaxyl and different herbicides, seem to exert no activity on spore germination even if the results obtained on the same substance in different investigations were often contradictory [28].

After germination, another important variable affecting the competitive ability of AMF towards native fungi is represented by the ability of germlings to produce an extensive and interconnected hyphal network, which is essential for increasing the chance of coming into contact with a host root. Germling growth may be affected by the same environmental variables quoted above, but depends largely on fungal genotype as it can range from 0.25 up to 104 and $544 \mathrm{~mm}$ of hyphal length per germling in the same experimental in vitro conditions [11]. It is important to underline that the possibility to contact host roots and to establish the symbiosis is greatly extended by the ability of germling 
hyphae to become interconnected through hyphal fusions (anastomoses): this capacity represents a fundamental survival strategy for AMF germlings, which can plug into compatible extraradical networks, gaining immediate access to plant-derived carbon [29]. Anastomosis formation is highly related to the fungal genotype, as species belonging to the families of Glomeraceae and Acaulosporaceae show a high frequency of hyphal fusions, while members of the family Gigasporaceae do not form fusions interconnecting different hyphae $[30,31]$. The length, viability, and interconnectedness of germling hyphae are affected by various pesticides: for example, fungicides containing benomyl and fenhexamid, even at doses below the recommended field rate, inhibited hyphal growth of $F$. mosseae, affected mycelial viability, and induced abnormal hyphal branching, while the herbicide glufosinate ammonium decreased mycelial growth and viability, and also the anastomosis rate [32,33].

When AMF germlings come into contact with a host root, a differential hyphal morphogenesis is induced, characterized by an increase in hyphal branching, functional to the production of appressoria on the root surface [12,34]. Appressoria are swollen, multinucleate structures formed as early as $36 \mathrm{~h}$ after the contact between germlings and roots [35], and represent the signs of fungal recognition of the host plant. A prompt production of a large number of appressoria, which is requisite for a rapid root colonization, characterizes the most infective AMF, as it makes them highly competitive with native symbionts. Several works investigated this AMF functional trait: an old, but not obsolete work, reported that the number of appressoria may range from 2.6 to 21.1 and from 4.6 to 10.7 per mm of root length in field-grown strawberry and apple, respectively [36], while more recent works found 10.2-80.5 appressoria per plant in parsley and aubergine inoculated in microcosms with F. mosseae $[37,38]$. The same fungus showed variable results depending on host plants: for example, it produced 3.6 appressoria per mm of root in Medicago truncatula, 9.7 in Prunus cerasifera, and 1.26 in Trifolium pratense [39-41]. On the other hand, G. margarita produced only 0.01 appressoria per mm of root when inoculated on Allium cepa [42]. The dynamics of appressoria formation was monitored in a time-course experiment, showing that the first structures were produced after 36,48 , and $60 \mathrm{~h}$, depending on the fungal genotype [35].

Appressoria produce intraradical hyphae able to establish the mycorrhizal symbiosis by rapidly spreading in the apoplastic space between root cortical cells, although the levels of root colonization greatly vary among AMF and plant genotypes. While such variability among different AMF species have been assessed in countless experiments aimed at evaluating fungal performance in terms of plant growth, the susceptibility of different plant genotypes to mycorrhizal colonization has been investigated only in recent works, reporting large differences among 11 sunflower cultivars (range 8.6-78.7\%) and 108 durum wheat varieties (range 10-44\%) $[43,44]$.

\subsection{Efficiency}

The efficiency of the different AM fungal isolates is generally interpreted as their ability to increase plant growth and nutrient uptake, and evaluated by considering the relevant fungal variables such as ERM development, extent, interconnectedness, viability, and rate of nutrient uptake and translocation, that are directly linked to the occurrence of fungal transporter genes in the absorptive extraradical hyphae [4].

ERM length density, assessed after destructive extraction from the soil, showed a large variability among AMF species, ranging from 1.1-6.9 to 3-5 and $10 \mathrm{~m} / \mathrm{g}$ soil in Acaulospora laevis, F. caledonius (formerly Glomus caledonium), and Scutellospora calospora, respectively [11]. Recent works have reported higher hyphal lengths (up to $22 \mathrm{~m} / \mathrm{g}$ soil) produced by $R$. irregulare isolate BEG 87 [45]. It is worth mentioning the ERM growth rate, which was 738-1067 and 3.1-3.8 mm/day in bidimensional and tri-dimensional experimental systems, respectively $[20,46]$.

ERM structure and interconnectedness have been investigated by nondestructive tests, which provided both qualitative $[47,48]$ and quantitative data. For example, ERM produced by members of the family Glomeraceae, widely distributed in agricultural soils, is highly interconnected by means of anastomoses between contacting hyphae (67-77\% in F. mosseae), reaching the value of 
$100-410$ anastomoses per gram of soil $[20,31,49]$. On the contrary, hyphae of members of the families Gigasporaceae, Ambisporaceae, and Paraglomeraceae are not able to fuse after contact, in vivo [50]. Nevertheless, within the Glomeraceae family, self-incompatible interactions between contacting hyphae may occur, with frequencies ranging from $5 \%$ to $32 \%$ [29,50,51]. Further extensive studies addressed such a clue, revealing major differences among three glomalean AMF: in particular, when grown in symbiosis with five different plant species, F. mosseae and R. irregulare ERM showed anastomosis frequency of $26-48 \%$ and $36-54 \%$, respectively, while F. coronatus never exceeded $7.7 \%$ [52]; length and density affect AMF symbiotic performance, positively correlating with plant growth responses and nutrient levels [53]. Specifically, AMF isolates showing a high anastomosing ability are able to tolerate soil disturbance, such as tillage, by producing large mycorrhizal networks capable of re-establish interconnections after disruption [54-57]. ERM length and structure may be affected by pesticides, as reported by a recent work performed using a whole-plant experimental system, i.e., in F. mosseae, ERM length and density decreased in the presence of the herbicides dicamba and glufosinolate and the fungicides benomyl and fenhexamid, while ERM length and density increased in the presence of two mycorrhizospheric bacteria, Ensifer meliloti (formerly Sinorhizobium meliloti) and Enterobacter ludwigii [58]. Such recent novel data stress the need for further studies to evaluate the impact of agrochemicals and biocontrol agents on ERM structure and activity in a large number of AMF taxa in order to detect the most resilient isolates able to maintain a high mycorrhizal inoculum potential in soil.

Beyond the mentioned phenotypic parameters, viability, which is the most important factor affecting ERM functionality in soil, has been poorly investigated. A few studies reported that metabolic activity occurred in $63-96 \%, 96-100 \%$, and 100\% of extraradical hyphae in R. irregulare, F. mosseae, and Rhizoglomus clarum (formerly Glomus clarum), respectively [46,59,60]. A recent study posed the interesting question of whether ERM could survive and maintain colonization ability after plant harvest, thus representing a source of inoculum for the successive crops. The authors, utilizing an in vivo whole-plant experimental system and two worldwide distributed glomalean AMF, F. mosseae and R. irregulare, revealed that ERM viability and functionality are uncoupled from the host plant lifespan, as, after shoot removal, its growth from detached roots was comparable with that from intact plants and continuous for at least 150 days [61]. Accordingly, ERM represents a long-term survival structure able to maintain mycorrhizal potential and biological fertility in agricultural soils.

AMF efficiency is highly correlated with the rate of $P$ translocation to the host plant: alas, only scanty information is available, showing that in F. mosseae, P fluxes in hyphae were $3.4 \times 10^{-8} \mathrm{~mol} \mathrm{~cm}^{-2} \mathrm{~s}^{-1}$ [62]. However, as the transfer of nutrients flowing in the extraradical hyphae can occur exclusively through appressoria, which are the unique structures connecting soil-based to root-based mycelium, a high number of appressoria produced on the root surface is a key factor affecting not only AMF colonization ability but also their efficiency.

Studies on the occurrence of nutrient transporter genes in AMF extraradical hyphae have mostly been performed in vitro, using transgenic root organ cultures and few species, i.e., $R$. irregulare and $R$. intraradices. The results showed that a number of nutrient transporter genes (ammonium, phosphorus, zinc) are differentially regulated, depending on the availability of various mineral or organic compounds $[4,63]$. However, as transformed roots show an altered hormonal balance and sugar acquisition, possibly affecting the physiology of the mycorrhizal symbiosis, diverse whole-plant experimental systems were devised, encompassing other AMF species, F. mosseae, F. coronatus, and G. margarita [64]. Further extensive investigations focusing on nutrient transporters gene expression in extraradical mycorrhizal mycelium produced by a large number of AMF isolates are needed in order to achieve a deeper knowledge of differences in AMF efficiency and to select the best performing symbionts to be used as inocula, if also meeting the other quality characteristics concerning colonization ability and efficiency. 


\section{AMF Efficiency in the Enhancement of Plant Health-Promoting Compounds}

In the light of the new findings on plant secondary metabolism being modulated by AMF, the concept of efficiency should be expanded to take into consideration the production of healthpromoting compounds, a theme of the highest concern not only to scientists but also to consumers and producers as phytochemicals may reduce oxidative damages, prevent chronic and heart diseases, and decrease the risk of mortality from cancer [65-67]. The levels of such compounds, mainly represented by carotenoids, glucosinolates, polyphenols, including flavonoids, isoflavones and anthocyanins, are affected by different variables such as plant genotype, agronomic techniques, soil characteristics, and also by mycorrhizal symbioses [6].

For example, sweet basil (Ocimum basilicum) inoculated with Glomus spp. increased the production of rosmarinic and caffeic acids, and of essential oils [68,69], while $R$. intraradices affected the gene expression of key enzymes involved in basil rosmarinic acid biosynthetic pathway [70]. Echinacea purpurea inoculated with $R$. irregulare and G. margarita showed higher concentrations of caffeic acid derivatives, alkylamides, and terpenes [71], while $R$. irregulare inoculated on Stevia rebaudiana enhanced its content of the health-promoting compound steviol glycoside [72]. Interestingly, diverse AMF isolates differentially affected the production of specific phytochemicals; for example, the levels of thymol derivatives in the roots of Inula ensifolia were more enhanced by R. clarus than by R. irregulare [73], while in basil leaves the production of camphor and alfa-terpineol were enhanced by Gigaspora rosea but not by G. margarita, which decreased the total content of essential oils, in particular that of eucalyptol, linalool, and eugenol [68].

Despite the good results obtained by utilizing medicinal plants and herbs, only a few food crops have been investigated for their levels of health-promoting compounds upon mycorrhizal inoculation, i.e., lettuce, onion, tomato, maize, artichoke, strawberry, pepper, and sweet potato [7]. Most experimental works utilized either AMF inocula composed of a mixture of species, obtained from commercial producers or single species inocula, often represented by $R$. irregulare or $F$. mosseae. Also, molecular studies focused on the assessment of the levels of transcripts encoding the enzymes of the pathways relevant to the production of health-promoting secondary metabolites mainly utilized the same two species [7]. This has impaired the evaluation of the efficiency of different AMF, aimed at selecting the best performing symbionts in the production of beneficial phytochemicals. Accordingly, in the years to come, in-depth investigations should fully exploit the wide physiological and genetic diversity of AMF, testing the highest possible range of diverse species, isolates, and lineages within isolates. In addition, transcriptomic studies would allow the identification of AMF strains differentially expressing genes relevant to the biosynthesis of nutraceutical compounds in food plants.

\section{Mycorrhizospheric Bacteria and Their Functional Significance}

It has long been known that AMF colonization ability and efficiency may be mediated by a third partner of the symbiosis, the diverse and abundant bacterial communities living in the mycorrhizosphere, i.e., associated with mycorrhizal roots, spores, sporocarps, and extraradical hyphae [74]. Later, by ultrastructural studies, bacteria were detected in spore wall layers, within the peridial hyphae surrounding spores [75,76], and inside the cytoplasm [77-80]. Culture-dependent approaches allowed the isolation of many different bacterial taxa from the mycorrhizosphere of Glomus versiforme, R. clarus, G. margarita, F. mosseae, and R. irregulare [81-84]. A recent work isolated from Rhizoglomus irregulare (formerly $R$. intraradices) spores as many as 374 bacterial strains [85]. Culture-independent methods provided an in-depth description of the different bacterial taxa associated with spores: for example, PCR denaturing gradient gel electrophoresis (PCR-DGGE) identified the bacterial communities associated with F. geosporus, Septoglomus constrictum, and G. margarita spores [23,24], and those strongly associated with the spores of six AMF isolates, three belonging to F. mosseae, one to F. coronatus, and two to R. irregulare-the 48 relevant sequences were affiliated with Actinomycetales, Bacillales, Burkholderiales, Pseudomonadales, Rhizobiales, and Mollicutes-related endobacteria [25]. 
The mycorrhizospheric microbiota showed different functional activities, ranging from the role of "mycorrhiza helper" (MH) [86] to that of "plant growth promoters" (PGP) (Figure 1). MH bacteria may increase spore germination and mycorrhizal symbiosis establishment: for example, Streptomyces spp., Pseudomonas sp., and Corynebacterium sp. improved the germination of $F$. mosseae, G. versiforme, and G. margarita spores [81,87-89]. The enhancement of spore germination was ascribed to Actinobacteria, a group of bacteria frequently associated with AMF spores, able to hydrolyze chitin, the main component of spore walls $[23,25,76,90]$. Other MH bacteria, such as Klebsiella pneumoniae, Trichoderma sp., and Paenibacillus validus, increased germlings hyphal growth [91-93], while one bacterial strain belonging to Oxalobacteriaceae enhanced not only spore germination and germling growth but also root colonization [94]. In addition, the development of AMF extraradical mycelium (ERM) may be promoted by strains of Paenibacillus rhizosphaerae, Azospirillum sp., Rhizobium etli, Pseudomonas spp., Burkolderia cepacia, and E. meliloti [45,95-98] (Figure 1).

PGP bacteria show multifunctional activities, encompassing nitrogen fixation, P solubilization and mineralization, the production of indole acetic acid (IAA), siderophores, and antibiotics while supplying fundamental nutrients and growth factors [8,9]. Such activities represent key characteristics to be taken into account when selecting the best AMF and bacterial combinations for the production of inocula for agricultural use. For example, as $\mathrm{P}$ is rapidly immobilized in the soil, forming insoluble compounds with aluminium/iron and with calcium in acid and alkaline soil and thus becoming unavailable to plants, P-solubilizing bacteria may work in synergy with AMF to increase P availability and plant P uptake. Indeed, P-mobilizing bacteria, such as Streptomyces spp., Leifsonia sp., Bacillus pumilus, Lisinobacillus fusiformis, and E. meliloti, isolated from AMF spores of $R$. irregulare, showed synergistic action with AMF, promoting the mineralization of soil phytate and facilitating P uptake by mycorrhizal plants $[45,99]$. Similarly, the isolation from the mycorrhizosphere of bacterial strains possessing the nifH gene amplicon suggested a possible role in plant acquisition of nitrogen [85]. On the other hand, some PGP bacteria are able to produce IAA, a phytohormone of the auxin class, which plays a key role in the regulation of plant growth, increasing plant cell division and root formation, thus affecting water and nutrient uptake [100-102]. Accordingly, IAA producing bacteria isolated from R. irregulare and F. mosseae, such as E. meliloti and Paenibacillus favisporus, enhanced the growth of AMF extraradical hyphae, the fungal structure fundamental for absorbing and translocating $P$ from the soil to plant roots $[45,95]$. An important role in the promotion of plant growth is played by mycorrhizospheric bacteria able to protect plants against soil-borne pathogens, either by directly producing antibiotics or indirectly producing siderophores, high-affinity iron-chelating compounds which mediate iron acquisition by pathogenic microorganisms [85,103-105]. Moreover, the facilitation of plant iron acquisition by siderophores-producing bacteria represents an additional benefit, as iron is an essential element in key biochemical processes like photosynthesis and respiration $[106,107]$. Interestingly, many of the bacteria isolated from AMF spores showed multiple PGP activities, i.e., 17 actinobacterial strains were able to produce siderophores and IAA to mineralize phytate and solubilize inorganic phosphate, and ten putative $\mathrm{N}$-fixers to produce siderophore and solubilize P [85]. A recent work confirmed such data, reporting the occurrence of diverse bacterial functional taxa in a commercial AMF inoculum: 14 isolates showed the best combination of PGP traits, such as the production of IAA and siderophores, while 6 of them were also able to solubilize P, i.e., Bacillus megaterium, Streptomyces sp., and Enterobacter spp. [108]. These strains, both as single- and multi-strain inocula, deserve further in-depth studies in order to evaluate their efficiency as biofertilizers and biostimulants, able to boost plant growth, nutrition and health in sustainable food production systems (Figure 1). New remarkable findings showed that several members of the mycorrhizospheric microbiota may establish a more intimate relationship with their host plants as root endophytes $[109,110]$ : considering that they can reach $10^{5}-10^{7} \mathrm{CFU}$ per $\mathrm{g}$ of root $[111,112]$, their possible beneficial effects should be further investigated in the years to come. 


\section{Conclusions and Perspectives for Future Studies}

The multiple beneficial activities of AMF and their associated bacteria discussed so far highlight the complex networks of interactions taking place in the mycorrhizosphere, functional to plant growth, nutrition, and health. The tripartite association among host plants, fungal symbionts and their associated bacteria shows beneficial emerging properties that could be efficiently exploited in sustainable food production. Although much is known on a very small number of AMF species, often studied singly in sterile conditions, very little is known about the high physiological and genetic interand intra-specific diversity of AMF and their associated microbiota. Further in-depth studies should be performed on different AMF species and isolates, and on their associated bacteria, both singly and in various combinations, in order to evaluate their colonization ability and efficiency when inoculated with a number of plant hosts. The studies carried out in microcosms should be followed by investigations in the field to assess the ability of the selected AMF and bacteria to compete with native microorganisms and to maintain their beneficial activities. Once detected as the best performing inocula, they could be differentiated by assessing their resilience against diverse environmental conditions, from soil types to drought, salt, biotic stresses, and pesticides. Transcriptomic studies could reveal the expression levels of nutrient transporter genes in fungal absorbing hyphae in the presence of selected efficient bacterial strains, possibly leading to the detection of the best synergistic combinations of AMF and associated bacterial communities, enhancing nutrient availability and plant performance. At the same time, transcriptomics could increase knowledge on the differential expression of genes encoding enzymes relevant to the biosynthesis of nutraceutical compounds in food plants. Eventually, newly designed multifunctional microbial consortia could be commercially reproduced and utilized as biofertilizers and biostimulants in sustainable and innovative production systems.

Author Contributions: M.A., A.T. and M.G. conceived the topic of the paper and wrote the original draft. L.G., M.P., L.A. and C.S. participated in the preparation and review of the manuscript. L.G. and M.P. provided editing assistance. All authors have read and agreed to the published version of the manuscript.

Funding: This work was funded by UNIVERSITY OF PISA, ITALY, grant: Fondi di Ateneo.

Conflicts of Interest: The authors declare no conflict of interest.

\section{References}

1. Food and Agriculture Organization. A Policymaker's Guide to the Sustainable Intensification of Smallholder Crop Production; FAO: Rome, Italy, 2011; Available online: http://www.fao.org/3/a-i2215e.pdf (accessed on 7 January 2020).

2. Philippot, L.; Raaijmakers, J.M.; Lemanceau, P.; Van Der Putten, W.H. Going back to the roots: The microbial ecology of the rhizosphere. Nat. Rev. Microbiol. 2013, 11, 789-799. [CrossRef]

3. Smith, S.E.; Read, D.J. Mycorrhizal Symbiosis, 3rd ed.; Academic Press: London, UK, 2008.

4. Casieri, L.; Ait Lahmidi, N.; Doidy, J.; Veneault-Fourrey, C.; Migeon, A.; Bonneau, L.; Courty, P.E.; Garcia, K.; Charbonnier, M.; Delteil, A.; et al. Biotrophic transportome in mutualistic plant-fungal interactions. Mycorrhiza 2013, 23, 597-625. [CrossRef]

5. Gianinazzi, S.; Gollotte, A.; Binet, M.N.; van Tuinen, D.; Redecker, D.; Wipf, D. Agroecology the key role of arbuscular mycorrhizas in ecosystem services. Mycorrhiza 2010, 20, 519-530. [CrossRef]

6. Sbrana, C.; Avio, L.; Giovannetti, M. Beneficial mycorrhizal symbionts affecting the production of health-promoting phytochemicals. Electrophoresis 2014, 35, 1535-1546. [CrossRef]

7. Avio, L.; Turrini, A.; Giovannetti, M.; Sbrana, C. Designing the ideotype mycorrhizal symbionts for the production of healthy food. Front. Plant Sci. 2018, 9, 1089. [CrossRef]

8. Barea, J.M.; Azcón, R.; Azcón-Aguilar, C. Mycorrhizosphere interactions to improve plant fitness and soil quality. Antonie Leeuwenhoek 2002, 81, 343-351. [CrossRef] [PubMed]

9. Rouphael, Y.; Franken, P.; Schneider, C.; Schwarz, D.; Giovannetti, M.; Agnolucci, M.; De Pascale, S.; Bonini, P.; Colla, G. Arbuscular mycorrhizal fungi act as biostimulants in horticultural crops. Sci. Hortic. 2015, 196, 91-108. [CrossRef] 
10. Turrini, A.; Avio, L.; Giovannetti, M.; Agnolucci, M. Functional complementarity of arbuscular mycorrhizal fungi and associated microbiota: The challenge of translational research. Front. Plant Sci. 2018, 9, 1407. [CrossRef] [PubMed]

11. Giovannetti, M.; Avio, L. Biotechnology of arbuscular mycorrhizas. In Applied Mycology and Biotechnology: Agriculture and Food Production; Khachatourians, G.G., Arora, D.K., Eds.; Elsevier: Amsterdam, The Netherlands, 2002; Volume 2, pp. 275-310.

12. Giovannetti, M.; Sbrana, C.; Avio, L.; Citernesi, A.S.; Logi, C. Differential hyphal morphogenesis in arbuscular mycorrhizal fungi during pre-infection stages. New Phytol. 1993, 125, 587-593. [CrossRef]

13. Akiyama, K.; Matsuzaki, K.I.; Hayashi, H. Plant sesquiterpenes induce hyphal branching in arbuscular mycorrhizal fungi. Nature 2005, 435, 824-827. [CrossRef]

14. Sbrana, C.; Giovannetti, M. Chemotropism in the arbuscular mycorrhizal fungus Glomus mosseae. Mycorrhiza 2005, 15, 539-545. [CrossRef]

15. Kiers, E.T.; Duhamel, M.; Beesetty, Y.; Mensah, J.A.; Franken, O.; Verbruggen, E.; Fellbaum, C.R.; Kowalchuk, G.A.; Hart, M.M.; Bago, A.; et al. Reciprocal rewards stabilize cooperation in the mycorrhizal symbiosis. Science 2011, 333, 880-882. [CrossRef]

16. Jiang, Y.; Wang, W.; Xie, Q.; Liu, N.; Liu, L.; Wang, D.; Zhang, X.; Yang, C.; Chen, X.; Tang, D.; et al. Plants transfer lipids to sustain colonization by mutualistic mycorrhizal and parasitic fungi. Science 2017, 356, 1172-1175. [CrossRef]

17. Luginbuehl, L.H.; Menard, G.N.; Kurup, S.; Van Erp,H.; Radhakrishnan, G.V.; Breakspear, A.; Oldroyd, G.E.D.; Eastmond, P.J. Fatty acids in arbuscular mycorrhizal fungi are synthesized by the host plant. Science 2017, 356, 1175-1178. [CrossRef]

18. Smith, F.A.; Smith, S.E. Tansley Review No. 96 structural diversity in (vesicular)-arbuscular mycorrhizal symbioses. New Phytol. 1997, 137, 373-388. [CrossRef]

19. Giovannetti, M.; Sbrana, C.; Avio, L.; Strani, P. Patterns of below-ground plant interconnections established by means of arbuscular mycorrhizal networks. New Phytol. 2004, 164, 175-181. [CrossRef]

20. Mikkelsen, B.L.; Rosendahl, S.; Jakobsen, I. Underground resource allocation between individual networks of mycorrhizal fungi. New Phytol. 2008, 180, 890-898. [CrossRef]

21. Giovannetti, M.; Avio, L.; Sbrana, C. Fungal spore germination and pre-symbiotic mycelial growth-physiological and genetic aspects. In Arbuscular Mycorrhizas: Physiology and Function; Koltai, H., Kapulnik, Y., Eds.; Springer: Dordrecht, The Netherlands, 2010; pp. 3-32. [CrossRef]

22. de Novais, C.B.; Sbrana, C.; Júnior, O.J.S.; Siqueira, J.O.; Giovannetti, M. Vegetative compatibility and anastomosis formation within and among individual germlings of tropical isolates of arbuscular mycorrhizal fungi (Glomeromycota). Mycorrhiza 2013, 23, 325-331. [CrossRef]

23. Roesti, D.; Ineichen, K.; Braissant, O.; Redecker, D.; Wiemken, A.; Aragno, M. Bacteria associated with spores of the arbuscular mycorrhizal fungi Glomus geosporum and Glomus constrictum. Appl. Environ. Microbiol. 2005, 71, 6673-6679. [CrossRef]

24. Long, L.; Zhu, H.; Yao, Q.; Ai, Y. Analysis of bacterial communities associated with spores of Gigaspora margarita and Gigaspora rosea. Plant Soil 2008, 310, 1-9. [CrossRef]

25. Agnolucci, M.; Battini, F.; Cristani, C.; Giovannetti, M. Diverse bacterial communities are recruited on spores of different arbuscular mycorrhizal fungal isolates. Biol. Fertil. Soils 2015, 51, 379-389. [CrossRef]

26. Giovannetti, M.; Turrini, A.; Strani, P.; Sbrana, C.; Avio, L.; Pietrangeli, B. Mycorrhizal fungi in ecotoxicological studies: Soil impact of fungicides, insecticides and herbicides. Prev. Today 2006, 2, 47-61.

27. Buysens, C.; Dupré de Boulois, H.; Declerck, S. Do fungicides used to control Rhizoctonia solani impact the non-target arbuscular mycorrhizal fungus Rhizophagus irregularis? Mycorrhiza 2015, 25, 277-288. [CrossRef] [PubMed]

28. Hage-Ahmed, K.; Rosner, K.; Steinkellner, S. Arbuscular mycorrhizal fungi and their response to pesticides. Pest Manag. Sci. 2019, 75, 583-590. [CrossRef] [PubMed]

29. Sbrana, C.; Fortuna, P.; Giovannetti, M. Plugging into the network: Belowground connections between germlings and extraradical mycelium of arbuscular mycorrhizal fungi. Mycologia 2011, 103, 307-316. [CrossRef] [PubMed]

30. Giovannetti, M.; Azzolini, D.; Citernesi, A.S. Anastomosis formation and nuclear and protoplasmic exchange in arbuscular mycorrhizal fungi. Appl. Environ. Microbiol. 1999, 65, 5571-5575. [CrossRef] 
31. Voets, L.; De La Providencia, I.E.; Declerck, S. Glomeraceae and Gigasporaceae differ in their ability to form hyphal networks. New Phytol. 2006, 172, 185-188. [CrossRef]

32. Chiocchio, V.; Venedikian, N.; Martinez, A.E.; Ana Menendez, A.M.; Ocampo, J.A.; Godeas, A. Effect of the fungicide benomyl on spore germination and hyphal length of the arbuscular mycorrhizal fungus Glomus mosseae. Int. Microbiol. 2000, 3, 173-175.

33. de Novais, C.B.; Giovannetti, M.; de Faria, S.M.; Sbrana, C. Two herbicides, two fungicides and spore-associated bacteria affect Funneliformis mosseae extraradical mycelium structural traits and viability. Mycorrhiza 2019, 29, 341-349. [CrossRef]

34. Buee, M.; Rossignol, M.; Jauneau, A.; Ranjeva, R.; Bécard, G. The pre-symbiotic growth of arbuscular mycorrhizal fungi is induced by a branching factor partially purified from plant root exudates. Mol. Plant Microbe Interact. 2000, 13, 693-698. [CrossRef]

35. Giovannetti, M.; Citernesi, A.S. Time-course of appressorium formation on host plants by arbuscular mycorrhizal fungi. Mycol. Res. 1993, 97, 1140-1142. [CrossRef]

36. Mosse, B. The regular germination of resting spores and some observations on the growth requirements of an Endogone sp. causing vesicular-arbuscular mycorrhiza. Trans. Br. Mycol. Soc. 1959, 42, 273-286. [CrossRef]

37. Breuninger, M.; Requena, N. Recognition events in AM symbiosis: Analysis of fungal gene expression at the early appressorium stage. Fungal Genet. Biol. 2004, 41, 794-804. [CrossRef] [PubMed]

38. Turrini, A.; Sbrana, C.; Pitto, L.; Ruffini Castiglione, M.; Giorgetti, L.; Briganti, R.; Bracci, T.; Evangelista, M.; Nuti, M.P.; Giovannetti, M. The antifungal Dm-AMP1 protein from Dahlia merckii expressed in Solanum melongena is released in root exudates and differentially affects pathogenic fungi and mycorrhizal symbiosis. New Phytol. 2004, 163, 393-403. [CrossRef]

39. Morley, C.D.; Mosse, B. Abnormal vesicular-arbuscular mycorrhizal infections in white clover induced by lupin. Trans. Br. Mycol. Soc. 1976, 67, 510-513. [CrossRef]

40. Fortuna, P.; Citernesi, S.; Morini, S.; Giovannetti, M.; Loreti, F. Infectivity and effectiveness of different species of arbuscular mycorrhizal fungi in micropropagated plants of Mr S 2/5 plum rootstock. Agronomie 1992, 12, 825-829. [CrossRef]

41. Staehelin, C.; Charon, C.; Boller, T.; Crespi, M.; Kondorosi, Á. Medicago truncatula plants overexpressing the early nodulin gene enod40 exhibit accelerated mycorrhizal colonization and enhanced formation of arbuscules. Proc. Natl. Acad. Sci. USA 2001, 98, 15366-15371. [CrossRef]

42. Tawaraya, K.; Hashimoto, K.; Wagatsuma, T. Effect of root exudate fractions from P-deficient and P-sufficient onion plants on root colonisation by the arbuscular mycorrhizal fungus Gigaspora margarita. Mycorrhiza 1998, 8, 67-70. [CrossRef]

43. Turrini, A.; Giordani, T.; Avio, L.; Natali, L.; Giovannetti, M.; Cavallini, A. Large variation in mycorrhizal colonization among wild accessions, cultivars, and inbreds of sunflower (Helianthus annuus L.). Euphytica 2016, 207, 331-342. [CrossRef]

44. De Vita, P.; Avio, L.; Sbrana, C.; Laidò, G.; Marone, D.; Mastrangelo, A.M.; Cattivelli, L.; Giovannetti, M. Genetic markers associated to arbuscular mycorrhizal colonization in durum wheat. Sci. Rep. 2018, 8, 10612. [CrossRef]

45. Battini, F.; Grønlund, M.; Agnolucci, M.; Giovannetti, M.; Jakobsen, I. Facilitation of phosphorus uptake in maize plants by mycorrhizosphere bacteria. Sci. Rep. 2017, 7, 4686. [CrossRef] [PubMed]

46. Giovannetti, M.; Fortuna, P.; Citernesi, A.S.; Morini, S.; Nuti, M.P. The occurrence of anastomosis formation and nuclear exchange in intact arbuscular mycorrhizal networks. New Phytol. 2001, 151, 717-724. [CrossRef]

47. Friese, C.F.; Allen, M.F. The spread of VA mycorrhizal fungal hyphae in the soil: Inoculum types and external hyphal architecture. Mycologia 1991, 83, 409-418. [CrossRef]

48. Bago, B.; Azcón-Aguilar, C.; Goulet, A.; Piché, Y. Branched absorbing structures (BAS): A feature of the extraradical mycelium of symbiotic arbuscular mycorrhizal fungi. New Phytol. 1998, 139, 375-388. [CrossRef]

49. Giovannetti, M.; Avio, L.; Sbrana, C. Functional significance of anastomosis in arbuscular mycorrhizal networks. In Mycorrhizal Networks; Horton, T., Ed.; Springer: Dordrecht, The Netherlands, 2015; Volume 224, pp. 41-67.

50. Purin, S.; Morton, J.B. In situ analysis of anastomosis in representative genera of arbuscular mycorrhizal fungi. Mycorrhiza 2011, 21, 505-514. [CrossRef]

51. Purin, S.; Morton, J.B. Anastomosis behavior differs between asymbiotic and symbiotic hyphae of Rhizophagus clarus. Mycologia 2013, 105, 589-602. [CrossRef] 
52. Pepe, A.; Giovannetti, M.; Sbrana, C. Different levels of hyphal self incompatibility modulate interconnectedness of mycorrhizal networks in three arbuscular mycorrhizal fungi within the Glomeraceae. Mycorrhiza 2016, 26, 325-332. [CrossRef]

53. Avio, L.; Pellegrino, E.; Bonari, E.; Giovannetti, M. Functional diversity of arbuscular mycorrhizal fungal isolates in relation to extraradical mycelial networks. New Phytol. 2006, 172, 347-357. [CrossRef]

54. Helgason, T.; Daniell, T.J.; Husband, R.; Fitter, A.H.; Young, J.P.W. Ploughing up the wood-wide web? Nature 1998, 394, 431. [CrossRef]

55. Simard, S.W.; Durrell, D.M. Mycorrhizal networks: A review of their extent, function and importance. Can. J. Bot. 2004, 82, 1140-1165. [CrossRef]

56. Avio, L.; Castaldini, M.; Fabiani, A.; Bedini, S.; Sbrana, C.; Turrini, A.; Giovannetti, M. Impact of nitrogen fertilization and soil tillage on arbuscular mycorrhizal fungal communities in a Mediterranean agroecosystem. Soil Biol. Biochem. 2013, 67, 285-294. [CrossRef]

57. Njeru, E.M.; Avio, L.; Sbrana, C.; Turrini, A.; Bocci, G.; Bàrberi, P.; Giovannetti, M. First evidence for a major cover crop effect on arbuscular mycorrhizal fungi and organic maize growth. Agron. Sustain. Dev. 2014, 34, 841-848. [CrossRef]

58. de Novais, C.B.; Avio, L.; Giovannetti, M.; de Faria, S.M.; Siqueira, J.O.; Sbrana, C. Interconnectedness, length and viability of arbuscular mycorrhizal mycelium as affected by selected herbicides and fungicides. Appl. Soil Ecol. 2019, 143, 144-152. [CrossRef]

59. Schubert, A.; Marzachi, C.; Mazzitelli, M.; Cravero, M.C.; Bonfante-Fasolo, P. Development of total and viable extraradical mycelium in the vesicular-arbuscular mycorrhizal fungus Glomus clarum Nicol. \& Schenck. New Phytol. 1987, 107, 183-190. [CrossRef]

60. Hamel, C.; Fyles, H.; Smith, D.L. Measurement of development of endomycorrhizal mycelium using three different vital stains. New Phytol. 1990, 115, 297-302. [CrossRef]

61. Pepe, A.; Giovannetti, M.; Sbrana, C. Lifespan and functionality of mycorrhizal fungal mycelium are uncoupled from host plant lifespan. Sci. Rep. 2018, 8, 10235. [CrossRef]

62. Sanders, F.E.; Tinker, P.B. Phosphate flow into mycorrhizal roots. Pestic. Sci. 1973, 4, 385-395. [CrossRef]

63. Ferrol, N.; Azcón-Aguilar, C.; Pérez-Tienda, J. Arbuscular mycorrhizas as key players in sustainable plant phosphorus acquisition: An overview on the mechanisms involved. Plant Sci. 2018, 280, 441-447. [CrossRef]

64. Pepe, A.; Sbrana, C.; Ferrol, N.; Giovannetti, M. An in vivo whole-plant experimental system for the analysis of gene expression in extraradical mycorrhizal mycelium. Mycorrhiza 2017, 7, 659-668. [CrossRef]

65. Johnson, I.T. Glucosinolates: Bioavailability and importance to health. Int. J. Vitam. Nutr. Res. 2002, 71, 26-31. [CrossRef]

66. Duthie, S.J. Plant polyphenols in cancer and heart disease: Implications as nutritional antioxidants. Nutr. Res. Rev. 2000, 13, 79-106. [CrossRef] [PubMed]

67. Lund, E. Non-nutritive bioactive constituents of plants: Dietary sources and health benefits of glucosinolates. Int. J. Vitam. Nutr. Res. 2003, 73, 135-143. [CrossRef] [PubMed]

68. Copetta, A.; Lingua, G.; Berta, G. Effects of three AM fungi on growth, distribution of glandular hairs, and essential oil production in Ocimum basilicum L. var. Genovese. Mycorrhiza 2006, 16, 485-494. [CrossRef]

69. Toussaint, J.P.; Kraml, M.; Nell, M.; Smith, S.E.; Smith, F.A.; Steinkellner, S.; Schmiderer, C.; Vierheilig, H.; Novak, J. Effect of Glomus mosseae on concentrations of rosmarinic and caffeic acids and essential oil compounds in basil inoculated with Fusarium oxysporum f. sp. basilici. Plant Pathol. 2008, 57, 1109-1116. [CrossRef]

70. Battini, F.; Bernardi, R.; Turrini, A.; Agnolucci, M.; Giovannetti, M. Rhizophagus intraradices or its associated bacteria affect gene expression of key enzymes involved in the rosmarinic acid biosynthetic pathway of basil. Mycorrhiza 2016, 26, 699-707. [CrossRef] [PubMed]

71. Gualandi, R.J., Jr. Fungal Endophytes Enhance Growth and Production of Natural Products in Echinacea Purpurea (Moench.). Master's Thesis, University of Tennessee, Knoxville, TN, USA, 2010. Available online: https://trace.tennessee.edu/utk_gradthes/713 (accessed on 7 January 2020).

72. Tavarini, S.; Passera, B.; Martini, A.; Avio, L.; Sbrana, C.; Giovannetti, M.; Angelini, L.G. Plant growth, steviol glycosides and nutrient uptake as affected by arbuscular mycorrhizal fungi and phosphorous fertilization in Stevia rebaudiana Bert. Ind. Crops Prod. 2018, 111, 899-907. [CrossRef]

73. Zubek, S.; Stojakowska, A.; Anielska, T.; Turnau, K. Arbuscular mycorrhizal fungi alter thymol derivative contents of Inula ensifolia L. Mycorrhiza 2010, 20, 497-504. [CrossRef] 
74. Rambelli, A. The rhizosphere of mycorrhizae. In Ectomycorrhizae: Their Ecology and Physiology; Marks, G.C., Kozlowski, T.T., Eds.; Academic Press: New York, NY, USA, 1973; pp. 299-343.

75. Walley, F.L.; Germida, J.J. Failure to decontaminate Glomus clarum NT4 spores is due to spore wall-associated bacteria. Mycorrhiza 1996, 6, 43-49. [CrossRef]

76. Filippi, C.; Bagnoli, G.; Citernesi, A.S.; Giovannetti, M. Ultrastructural spatial distribution of bacteria associated with sporocarps of Glomus mosseae. Symbiosis 1998, 24, 1-12.

77. Mosse, B. Honey-coloured, sessile Endogone spores: II. Changes in fine structure during spore development. Arch. Mikrobiol. 1970, 74, 129-145. [CrossRef]

78. MacDonald, R.M.; Chandler, M.R. Bacterium-like organelles in vesicular-arbuscular mycorrizal fungus Glomus caledonium. New Phytol. 1981, 89, 241-246. [CrossRef]

79. MacDonald, R.M.; Chandler, M.R.; Mosse, B. The occurrence of bacterium-like organelles in vesiculararbuscular mycorrizal fungi. New Phytol. 1982, 90, 659-663. [CrossRef]

80. Bianciotto, V.; Bandi, C.D.; Minerdi, M.; Sironi, H.; Tichy, V.; Bonfante, P. An obligately endosymbiotic mycorrhizal fungus itself harbors obligately intracellular bacteria. Appl. Environ. Microbiol. 1996, 62, 3005-3010. [CrossRef]

81. Mayo, K.; Davis, R.E.; Motta, J. Stimulation of germination of spores of Glomus versiforme by spore-associated bacteria. Mycologia 1986, 78, 426-431. [CrossRef]

82. Xavier, L.J.C.; Germida, J.J. Bacteria associated with Glomus clarum spores influence mycorrhizal activity. Soil Biol. Biochem. 2003, 35, 471-478. [CrossRef]

83. Bharadwaj, D.P.; Lundquist, P.O.; Persson, P.; Alström, S. Evidence for specificity of cultivable bacteria associated with arbuscular mycorrhizal fungal spores. FEMS Microbiol. Ecol. 2008, 65, 310-322. [CrossRef]

84. Cruz, A.F.; Horii, S.; Ochiai, S.; Yasuda, A.; Ishii, T. Isolation and analysis of bacteria associated with spores of Gigaspora margarita. J. Appl. Microbiol. 2008, 104, 1711-1717. [CrossRef]

85. Battini, F.; Cristani, C.; Giovannetti, M.; Agnolucci, M. Multifunctionality and diversity of culturable bacterial communities strictly associated with spores of the plant beneficial symbiont Rhizophagus intraradices. Microbiol. Res. 2016, 183, 68-79. [CrossRef]

86. Frey-Klett, P.; Garbaye, J.A.; Tarkka, M. The mycorrhiza helper bacteria revisited. New Phytol. 2007, 176, 22-36. [CrossRef]

87. Mugnier, J.; Mosse, B. Spore germination and viability of a vesicular arbuscular mycorrhizal fungus, Glomus mosseae. Trans. Br. Mycol. Soc. 1987, 88, 411-413. [CrossRef]

88. Tylka, G.L.; Hussey, R.S.; Roncadori, R.W. Axenic germination of vesicular-arbuscular mycorrhizal fungi: Effects of selected Streptomyces species. Phytopathology 1991, 81, 754-759. [CrossRef]

89. Carpenter-Boggs, L.; Loynachan, T.E.; Stahl, P.D. Spore germination of Gigaspora margarita stimulated by volatiles of soil-isolated actinomycetes. Soil Biol. Biochem. 1995, 27, 1445-1451. [CrossRef]

90. Ames, R.N.; Mihara, K.L.; Bayne, H.G. Chitin-decomposing actynomycetes associated with a vesiculararbuscular mycorrhizal fungus from a calcareous soil. New Phytol. 1989, 111, 67-71. [CrossRef]

91. Will, M.E.; Sylvia, D.M. Interaction of rhizosphere bacteria, fertilizer, and vesicular-arbuscular mycorrhizal fungi with sea oats. Appl. Environ. Microbiol. 1990, 56, 2073-2079. [CrossRef]

92. Calvet, C.; Barea, J.M.; Pera, J. In vitro interactions between the vesicular-arbuscular mycorrhizal fungus Glomus mosseae and some saprophytic fungi isolated from organic substrates. Soil Biol. Biochem. 1992, 24, 775-780. [CrossRef]

93. Hildebrandt, U.; Ouziad, F.; Marner, F.-J.J.; Bothe, H. The bacterium Paenibacillus validus stimulates growth of the arbuscular mycorrhizal fungus Glomus intraradices up to the formation of fertile spores. FEMS Microbiol. Lett. 2006, 254, 258-267. [CrossRef]

94. Pivato, B.; Offre, P.; Marchelli, S.; Barbonaglia, B.; Mougel, C.; Lemanceau, P. Bacterial effects on arbuscular mycorrhizal fungi and mycorrhiza development as influenced by the bacteria, fungi, and host plant. Mycorrhiza 2009, 19, 81-90. [CrossRef]

95. Bidondo, L.F.; Silvani, V.; Colombo, R.; Pérgola, M.; Bompadre, J.; Godeas, A. Pre-symbiotic and symbiotic interactions between Glomus intraradices and two Paenibacillus species isolated from AM propagules. In vitro and in vivo assays with soybean (AG043RG) as plant host. Soil Biol. Biochem. 2011, 43, 1866-1872. [CrossRef]

96. Ordoñez, Y.M.; Fernandez, B.R.; Lara, L.S.; Rodriguez, A.; Uribe-Vélez, D.; Sanders, I.R. Bacteria with phosphate solubilizing capacity alter mycorrhizal fungal growth both inside and outside the root and in the presence of native microbial communities. PLOS ONE 2016, 11, e0154438. [CrossRef] 
97. Ravnskov, S.; Jakobsen, I. Effects of Pseudomonas fluorescens DF57 on growth and P uptake of two arbuscular mycorrhizal fungi in symbiosis with cucumber. Mycorrhiza 1999, 8, 329-334. [CrossRef]

98. Ravnskov, S.; Larsen, J.; Jakobsen, I. Phosphorus uptake of an arbuscular mycorrhizal fungus is not effected by the biocontrol bacterium Burkholderia cepacia. Soil Biol. Biochem. 2002, 34, 1875-1881. [CrossRef]

99. Zhang, L.; Fan, J.; Ding, X.; He, X.; Zhang, F.; Feng, G. Hyphosphere interactions between an arbuscular mycorrhizal fungus and a phosphate solubilizing bacterium promote phytate mineralization in soil. Soil Biol. Biochem. 2014, 74, 177-183. [CrossRef]

100. Khalid, A.; Arshad, M.; Kahir, Z.A. Screening plant growth promoting rhizobacteria for improving growth and yield of wheat. J. Appl. Microbiol. 2004, 96, 473-480. [CrossRef] [PubMed]

101. Aloni, R.; Aloni, E.; Langhans, M.; Ullrich, C.I. Role of cytokinin and auxin in shaping root architecture: Regulating vascular differentiation, lateral root initiation, root apical dominance and root gravitropism. Ann. Bot. 2006, 97, 883-893. [CrossRef] [PubMed]

102. Duca, D.; Lorv, J.; Patten, C.L.; Rose, D.; Glick, B.R. Indole-3- acetic acid in plant-microbe interactions. Antonie Leeuwenhoek 2014, 106, 85-125. [CrossRef] [PubMed]

103. Budi, S.W.; van Tuinen, D.; Martinotti, G.; Gianinazzi, S. Isolation from Sorghum bicolor mycorrhizosphere of a bacterium compatible with arbuscular mycorrhiza development and antagonistic towards soil-borne fungal pathogens. Appl. Environ. Microbiol. 1999, 65, 5148-5150. [CrossRef] [PubMed]

104. Li, B.; Ravnskov, S.; Xie, G.; Larsen, J. Biocontrol of Pythium damping-off in cucumber by arbuscular mycorrhiza-associated bacteria from the genus Paenibacillus. Biocontrol 2007, 52, 863-875. [CrossRef]

105. Bharadwaj, D.P.; Lundquist, P.O.; Alström, S. Arbuscular mycorrhizal fungal spore-associated bacteria affect mycorrhizal colonization, plant growth and potato pathogens. Soil Biol. Biochem. 2008, 40, 2494-2501. [CrossRef]

106. Kobayashi, T.; Nishizawa, N.K. Iron uptake, translocation, and regulation in higher plants. Ann. Rev. Plant Biol. 2012, 63, 131-152. [CrossRef]

107. Robin, A.; Vansuyt, G.; Hinsinger, P.; Meyer, J.M.; Briat, J.F.; Lemanceau, P. Iron dynamics in the rhizosphere: Consequences for plant health and nutrition. Adv. Agron. 2008, 99, 183-225. [CrossRef]

108. Agnolucci, M.; Avio, L.; Pepe, A.; Turrini, A.; Cristani, C.; Bonini, P.; Cirino, V.; Colosimo, F.; Ruzzi, M.; Giovannetti, M. Bacteria associated with a commercial mycorrhizal inoculum: Community composition and multifunctional activity as assessed by Illumina sequencing and culture-dependent tools. Front. Plant Sci. 2018, 9, 1956. [CrossRef] [PubMed]

109. Le Cocq, K.; Gurr, S.J.; Hirsch, P.R.; Mauchline, T.H. Exploitation of endophytes for sustainable agricultural intensification. Mol. Plant Pathol. 2017, 18, 469-473. [CrossRef]

110. Agnolucci, M.; Palla, M.; Cristani, C.; Cavallo, N.; Giovannetti, M.; De Angelis, M.; Gobbetti, M.; Minervini, F. Beneficial Plant Microorganisms Affect the Endophytic Bacterial Communities of Durum Wheat Roots as Detected by Different Molecular Approaches. Front. Microbiol. 2019, 10, 2500. [CrossRef] [PubMed]

111. Compant, S.; Clément, C.; Sessitsch, A. Plant growth-promoting bacteria in the rhizo- and endosphere of plants: Their role, colonization, mechanisms involved and prospects for utilization. Soil Biol. Biochem. 2010, 42, 669-678. [CrossRef]

112. Hardoim, P.R.; van Overbeek, P.S.; Berg, G.; Pirttilä, A.M.; Compant, S.; Campisano, A.; Döring, M.; Sessitsch, A. The hidden world within plants: Ecological and evolutionary considerations for defining functioning of microbial endophytes. Microbiol. Mol. Biol. Rev. 2015, 79, 293-320. [CrossRef] [PubMed]

(C) 2020 by the authors. Licensee MDPI, Basel, Switzerland. This article is an open access article distributed under the terms and conditions of the Creative Commons Attribution (CC BY) license (http://creativecommons.org/licenses/by/4.0/). 